\title{
UK PARENTS' PERCEPTIONS OF ENGAGEMENT THROUGH DIGITAL TECHNOLOGY DURING THE COVID-19 PANDEMIC: A PRELIMINARY ANALYSIS
}

\author{
M. Bond ${ }^{1}$, N. Bergdahl ${ }^{2}$ \\ ${ }^{1}$ EPPI-Centre, Institute of Education, University College London (UNITED KINGDOM) \\ ${ }^{2}$ Department of Computer and Systems Sciences, Stockholm University (SWEDEN)
}

\begin{abstract}
Parent involvement in and engagement with children's learning, play an important role in influencing schoolchildren's engagement, achievement, and school completion; this became even more crucial during the COVID-19 pandemic that swept the world in early 2020. Given the paucity of research exploring parental attitudes to and experiences of blended and online learning, both before and during the pandemic, a case study of parents in the United Kingdom (UK) $(n=552$, representing 1,038 schoolaged children) was conducted from June to September 2020, using an online survey, with both closed and open-ended questions, as well as semi-structured interviews $(n=14)$. The survey results revealed that the schoolchildren mostly used a laptop, tablet or smartphone to undertake their learning, with parents reporting a rise in the use of live lesson, videos, Google Classroom, and online communities during lockdown, reflecting the tools that parents found were most useful for their children's learning, as well as the most engaging. Whilst parents felt slightly more aware of the work their children were doing, they reported that they felt less connected to the school community, and that their children were not more engaged or learning better as a result of using technology during the lockdown.
\end{abstract}

Keywords: COVID-19, parent involvement, student engagement, digital technology, emergency remote teaching, K-12.

\section{INTRODUCTION}

Parent involvement in and engagement with children's learning have been shown to strongly influence engagement, motivation, achievement, and school completion ([1], [2], [3]). Familial factors that have been shown to influence teaching and learning include parental attitude towards learning, self-efficacy, engagement with tasks and activities, level of communication with schools, and ICT skills and knowledge ([4], [5]); factors that became abundantly more evident and important during the COVID-19 pandemic ([6]). Pedagogical approaches utilising digital technologies, such as the flipped learning approach, have previously pointed towards enhanced parental and student engagement in learning ([7]). Whilst digital learning materials have the potential to enable parents' involvement in their children's schoolwork ([8], [9]), evidence of and guidance for schools to effectively use technology to enhance parent engagement has been limited ([10], [11]). Furthermore, the abrupt switch to emergency remote education meant intense professional development for teachers [12]), ([13]); introducing new ways of teaching and learning involving digital technologies that many were not prepared for, or experienced with ([7], [12]).

Despite many schools and teachers around the world reporting that digital technologies were satisfactory during the pandemic, and had prevented a collapse of the educational system ([13]), there have been serious concerns in relation to digital inequality, impacting teaching and learning during the lockdown, including a lack of digital infrastructure, access to devices, or knowledge and support on how to use digital technologies and resources for learning ([14], [15], [16], [17]). Reports have highlighted an imminent risk that a large proportion of students will fall behind and that they will not receive the education they are entitled to ([18]). The OECD ([19]) found a $40 \%$ difference in the availability of adequate digital technologies between advantaged and disadvantaged schools. Other studies have nuanced this further and concluded that almost one-third of Italian students had not been able to participate in distance education ([17]), and that half of German students could participate in online teaching once a week, with only $6 \%$ receiving education every day ([20]).

The situation was similar in the UK ([21]), where all schools were closed by 20th March 2020, except for vulnerable children and the children of those considered to be essential workers ([22]). A study of 5,582 families in England ([23]), carried out during the beginning of the first lockdown, found that $10 \%$ of children in primary school were using a mobile phone for learning or had no access to a device at all, and only around half had access to a computer for learning. However, even in cases where families did 
have access to devices, they reported difficulties accessing online materials and being told how they could effectively support their children's learning. In Northern Ireland, for example, a survey of 1,905 parents to children in post-primary school ([24]) found that whilst $87 \%$ of parents reported their children using Learning Management Systems (LMS) such as Google Classroom or Seesaw, only $54 \%$ were shown how to access the online materials provided, and $65 \%$ of parents reported having difficulties in supporting their children's learning. Parent-teacher communication, and teacher-student communication (i.e., giving schoolwork feedback), were other difficulties that parents reported on ([25]). Parents of school children with special educational needs and disabilities (SEND) were particularly concerned about not receiving adequate instructions (i.e., how to use digital technologies, not being provided with differentiated materials and knowledge to guide their children's learning) ([26]).

A rapid review of COVID-19 related research exploring teaching and learning during the pandemic, revealed that $12 \%$ of studies included participants from the UK ([6]), but only four of these focused on parent perceptions ([26], [27], [28], [29]). Given the importance of parent engagement for children's learning, and the relative paucity of research exploring parental attitudes to and experiences of blended and online learning, both before and during the pandemic, this paper seeks to gain a deeper understanding of parent perceptions of digital technologies used during the first lockdown in the UK, but perhaps more importantly, to gain an insight into how digital technologies could be harnessed going forwards, and incorporated into teachers' regular practices ([12], [13]). Against this background, the questions this paper seeks to answer are:

1 What devices did school children in the UK have access to at home during the COVID-19 pandemic?

2 What digital technologies do parents report schools used before and during the pandemic?

3 What are parents' perceptions of the digital technologies used by their children for learning during the pandemic?

4 How did digital technologies affect parent engagement in their children's schoolwork?

\section{METHODOLOGY}

This paper is a part of a more extensive mixed methods study ([31]), which aims to capture both quantitative aspects, lived experiences and attitudes of parents with schoolchildren in the UK, and the use of digital technology tools for learning during the COVID-19 pandemic. An online survey was distributed to answer the research questions. Semi-structured interviews were also undertaken, which will be published elsewhere. Due to lockdown, participants were sought through a virtual social media snowballing strategy ([32]), using Twitter, Facebook, and advertising online through UK university networks. Participants were encouraged to share the study with other parents they knew and to share or retweet the post online. Organisations such as Parentkind ${ }^{1}$ were also contacted, and shared the survey with parents in their networks. Although it is acknowledged that a snowball sampling technique can exclude the possibility of some participants becoming involved due to not being part of particular social networks ([33]), limited digital skills or low socioeconomic status ([34]), a modified snowball sampling technique using social media was employed. This technique has been found effective for the recruitment of parents and families to studies ([34], [35]).

\subsection{Data collection}

Initial ethical approval was sought and granted by the University College London (UCL) Institute of Education (REC 1371, data protection registration number Z6364106/2020/06/14) before the study. Data were collected through an online survey using Survey Monkey ([36]) between June and August 2020 , which began with information about the purpose of the study, with participants then providing informed consent; acknowledging that they understood their participation would be anonymous and that they were free to withdraw at any time. Participants answered demographic questions (relating to the country of residence, number of children, age of children and year level of children, level and type of schooling), as well as both 5-point Likert questions and open-ended questions, sourced from previously validated instruments; the 'Media Use Survey' ([37]), the 'I\&CT Scale' ([38]), 'Parent eLearning Perception' survey ([39]), and the 'Online Learning Readiness Scale' ([38]), which were also used in a previous study on parent engagement and flipped learning ([8]). Some questions were adapted or added

\footnotetext{
${ }^{1}$ https://www.parentkind.org.uk/
} 
to fit the current circumstances, e.g. 'Do you feel that your child's school was quick to start using digital technology following lockdown? Why/why not?'.

\subsection{Data analysis}

Descriptive statistics were analysed using JASP version 0.14 .1 and Excel version 16.48 . While not all questions in the survey were compulsory, data were checked for missing values, which are reported with each question. The open-ended questions within the survey were read and open coded ([40]) by highlighting phrases or sentences that identified how parents perceived the use of digital technologies during the lockdown, as well as their connection to and communication with their children's school/s, which were then classed into more refined themes and categories (All data can be accessed from [36]).

\subsection{Participants}

552 survey responses were received from parents of children in primary and secondary school in the UK (see Table 1).

Table 1. Number of children per family across the sample

\begin{tabular}{|c|c|c|c|c|c|}
\hline Demographic table of respondents & $n$ & $\%$ & Cumulative \% & Mean & $S D$ \\
\hline \multicolumn{6}{|l|}{ Region } \\
\hline England & 474 & 85.9 & 85.9 & & \\
\hline Northern Ireland & 17 & 3.1 & 89.0 & & \\
\hline Scotland & 42 & 7.6 & 96.6 & & \\
\hline Wales & 19 & 3.4 & 100 & & \\
\hline \multicolumn{6}{|l|}{ School level represented per household } \\
\hline Primary school & 221 & 40.0 & 40.0 & & \\
\hline Primary and secondary school & 173 & 31.3 & 71.3 & & \\
\hline Secondary school & 158 & 28.6 & 100 & & \\
\hline \multicolumn{6}{|l|}{ School-aged children per household * } \\
\hline 1 child & 174 & 31.5 & 31.5 & & \\
\hline 2 children & 274 & 49.6 & 81.2 & & \\
\hline 3 children & 84 & 15.2 & 96.4 & & \\
\hline 4 children & 17 & 3.1 & 99.5 & & \\
\hline 5 children & 3 & 0.5 & 100 & & \\
\hline Average of school aged children per household & & & & 1.92 & 0.80 \\
\hline
\end{tabular}

${ }^{*}$ Numbers refer to the number of children in primary and secondary school as reported by parents. Respondents with children in nursery, infant school or Year 6 in Middle School were considered part of the primary school sample.

The parents surveyed have 1,038 school-aged children between them (1,057 children total), the majority of whom attended a state (government) school (92\% parent respondents, $n=507)$ during the study period. Most parents have one or two children, with quite an even spread across year levels; although the highest reported year level was Year 5 ([see 36]).

\section{RESULTS AND DISCUSSION}

\subsection{Device access during lockdown}

The most popular device that children had access to was a notebook or a laptop $(73.64 \%, n=405)$, followed by a tablet/iPad $(66.55 \%, n=366)$ and a smartphone with internet access $(64.97 \%, n=357)$. Interestingly, there was a difference between the number of parents who indicated their primary school only children had access to a tablet $(75 \%, n=161)$ compared to secondary school only children $(47 \%$, $n=75$ ). Notably, several parents mentioned having to share their work laptop with their children, as they did not have a spare device, which was also found to be the case for families with primary school children in Scotland ([25]). Only 30\% of families reported using a desktop computer, although a surprising number of families had a printer $(63.64 \%, n=350)$. Generally, parents in the survey reported reasonable 
internet connection quality, with $56.47 \%(n=310)$ reporting that their connection was 'very good' or 'excellent'. Only $7.47 \%(n=41)$ reported that the speed is slow and that they have regular connection issues, and $1.28 \%(n=7)$ indicated that their connection is terrible, including two families who indicated they did not have an internet connection at home.

\subsection{Digital technology used for learning and communication in the UK}

Parents were asked to identify which digital technology tools schools had been using for learning and communication prior to and during the lockdown; 454 parents answered (see Table 2 for top ten and [36] for the full table).

Table 2. Most frequently used technology tools by teachers for teaching, learning and communication before and during the COVID-19 pandemic, as perceived by parents

\begin{tabular}{lccccc}
\hline Digital technology & $\begin{array}{c}\text { Rank (before } \\
\text { COVID-19) }\end{array}$ & $\begin{array}{c}\text { Rank (during } \\
\text { COVID-19) }\end{array}$ & $\begin{array}{c}\text { \% (before } \\
\text { COVID-19) }\end{array}$ & $\begin{array}{c}\text { \% (during } \\
\text { COVID-19) }\end{array}$ & Difference \\
\hline School email & 1 & 1 & $67 \%$ & $44 \%$ & $\downarrow 23 \%$ \\
Search engines & 2 & 6 & $49 \%$ & $25 \%$ & $\downarrow 24 \%$ \\
School LMS & 3 & 3 & $37 \%$ & $36 \%$ & $\downarrow 1 \%$ \\
Videos on YouTube & 4 & 4 & $27 \%$ & $29 \%$ & $\uparrow 2 \%$ \\
Social networks & 5 & 10 & $23 \%$ & $12 \%$ & $\downarrow 11 \%$ \\
Videos on school LMS & 6 & 7 & $15 \%$ & $24 \%$ & $\uparrow 9 \%$ \\
Class Dojo & 7 & 12 & $14 \%$ & $7 \%$ & $\downarrow 7 \%$ \\
Google Classroom & 8 & 5 & $13 \%$ & $27 \%$ & $\uparrow 14 \%$ \\
Music & 9 & 12 & $12 \%$ & $7 \%$ & $\downarrow 5 \%$ \\
Chat/instant messaging & $=$ & 10 & $12 \%$ & $12 \%$ & $=$ \\
Cloud storage & 10 & 11 & $11 \%$ & $9 \%$ & $\downarrow 2 \%$ \\
Photo communities & $=$ & 14 & $11 \%$ & $4 \%$ & $\downarrow 7 \%$ \\
\hline
\end{tabular}

*In Table 2 (=) refers to no change in the level of use

Before COVID-19, school email was the most used technology, with respondents reporting its use for $67 \%$ of their children and one parent crediting receiving emails from teachers with "keep[ing their] child motivated [and being]... the most engaging" tool (Participant 490, Parent to children in Year 3 and Year 13). However, even though it remained the most used tool for learning and communication during lockdown, the rate of reported use dropped by $23 \%$, with this rate even higher for families with secondary school children only (36\% decrease). Given the shift to emergency remote education, it is perhaps unsurprising that group/class conference calls saw a $39 \%$ increase overall, although there was some disparity between primary school only families ( $27 \%$ increase) and secondary school only families $(52 \%)$. This difference in the use of live, synchronous video calls reflects previous findings in the UK Household Longitudinal Study ([29]), where one-third of children in secondary school were found to be receiving at least one online lesson a day, compared to $28 \%$ of children in primary school. In contrast to this, videos available on school LMS and videos on YouTube increased for the children of primary school only families (19\% and $17 \%$ increase respectively). In contrast, they were reported to reduce for secondary school only families ( $3 \%$ and $15 \%$ decrease respectively). Aside from an increase in the use of collaborative online communities, such as Google Classroom, other asynchronous tools that promote interaction and collaboration, such as social networking apps, wikis, chat/instant messaging, and microblogging, were also reported to decrease for children in secondary school $(22 \%, 5 \%, 8 \%$ and $9 \%$ decreases respectively).

\subsection{Parent attitudes towards and perceptions of digital technology tools during the pandemic}

To gain an understanding of parent attitudes and perceptions of digital technology, participants were first asked to rate their IT skills, knowledge and use on a 5-point Likert scale ([36]). The parents in this sample consider themselves confident users of IT; they feel very confident in using Microsoft Office programs $(M=4.35, S D=0.97)$, using the internet to find and gather information $(M=4.71, S D=0.63)$, using the internet to communicate with others (e.g., via email) $(M=4.25, S D=0.91)$, as well as to share new information with others $(M=4.12, S D=1.02)$. They feel slightly less confident with using 
collaborative documents online $(M=3.44, S D=1.32)$, backing up data $(M=3.06, S D=1.39)$ and categorising emails $(M=2.95, S D=1.46)$. Despite this, these parents feel that it is important for their children's future to know about $(M=4.38, S D=0.84)$ and use online learning tools $(M=4.29, S D=$ $0.90)$, and they encourage their children to learn new things via online learning $(M=4.07, S D=0.96)$.

Parents were also asked to rate how useful various digital technology tools have been for learning during the pandemic on a 5-point Likert scale, with 1 being 'Not useful at all' and 5 being 'Very useful', to which 424 parents responded (see [36]). Interestingly, search engines were identified as the most useful by parents $(M=4.26, S D=1.06)$, despite a $23 \%$ decrease during the lockdown, with a staggering $40 \%$ decrease in use reported by parents of children in secondary school. Online classroom communities where school children "can communicate with [their] teachers" (Participant 496, Parent to child in Year 8) and where "everything [is] in one place [with] easy access to materials" (Participant 501, Parent to child in Year 11), such as Google Classroom, were rated second most useful ( $M=3.87$, SD $=1.43$ ), followed by videos found on YouTube $(M=3.83, S D=1.09)$ and videos on school $L M S(M=3.68, S D$ $=1.22$ ), as they can "illustrate small parts of work and methods" (Participant 521, Parent to children in Year 10 and 12). Group/class conference calls were also found useful $(M=3.74, S D=1.37)$, as "it enabled the children to communicate in small groups...[and] from there they would continue their work with teacher-led tasks" (Participant 49, Parent to children in Reception and Year 6). Interestingly, despite the use of email having decreased substantially, parents ranked it the eighth most useful tool $(M=3.45$, $S D=1.40$ ), particularly for sending resources as some "won't load in old computers with old browsers" (Participant 349, Parent to children in Year 9 and Year 11), as well as being useful for receiving feedback and staying in touch with teachers and the school community.

\subsection{Digital technology and engagement during the pandemic}

Parents were asked to identify specific digital technologies that engaged their children in learning during the pandemic, with 381 parents identifying 145 unique tools or devices.

Table 3. Parent-reported engagement for themselves and their child(ren)

\begin{tabular}{|c|c|c|c|c|c|c|}
\hline \multirow[t]{2}{*}{ Parental engagement statements } & \multicolumn{2}{|c|}{$\begin{array}{l}\text { Overall } \\
(n=424)\end{array}$} & \multicolumn{2}{|c|}{$\begin{array}{l}\text { Primary only } \\
\quad(n=165)\end{array}$} & \multicolumn{2}{|c|}{$\begin{array}{c}\text { Sec. only } \\
(n=125)\end{array}$} \\
\hline & M & $S D$ & M & $S D$ & M & $S D$ \\
\hline $\begin{array}{l}\text { My children feel more engaged with learning as a result of using } \\
\text { educational technology during lockdown. }\end{array}$ & 2.34 & 1.19 & 2.25 & 1.19 & 2.41 & 1.21 \\
\hline $\begin{array}{l}\text { Recorded lectures/explanations help my children because they can } \\
\text { rewatch portions of lessons that they do not understand. }\end{array}$ & 3.03 & 1.25 & 2.75 & 1.25 & 3.30 & 1.23 \\
\hline $\begin{array}{l}\text { My children have been learning better since using online tools during } \\
\text { lockdown. }\end{array}$ & 2.29 & 1.21 & 2.24 & 1.22 & 2.41 & 1.24 \\
\hline $\begin{array}{l}\text { Since lockdown, my children have a sense of responsibility for their } \\
\text { learning. }\end{array}$ & 2.77 & 1.32 & 2.37 & 1.21 & 3.02 & 1.39 \\
\hline $\begin{array}{l}\text { I watch/see some of my children's learning activities of videos at least } \\
\text { once a day. }\end{array}$ & 3.64 & 1.27 & 3.86 & 1.20 & 3.21 & 1.36 \\
\hline $\begin{array}{l}\text { I am more aware of the work that my children do for school as a result } \\
\text { of using educational technology during lockdown. }\end{array}$ & 3.42 & 1.30 & 3.42 & 1.42 & 3.27 & 1.21 \\
\hline $\begin{array}{l}\text { I am having more discussion with my children's teacher(s) as a result of } \\
\text { using educational technology during lockdown. }\end{array}$ & 2.34 & 1.28 & 2.32 & 1.35 & 2.42 & 1.23 \\
\hline $\begin{array}{l}\text { I feel more connected to the school community as a result of the } \\
\text { lockdown. }\end{array}$ & 2.27 & 1.24 & 2.20 & 1.30 & 2.34 & 1.20 \\
\hline
\end{tabular}

Whilst 49 parents $(12.86 \%)$ responded that no tools or devices had been found engaging, Google Classroom was ranked the highest $(20.73 \%, n=79)$, followed by YouTube videos $(16.54 \%, n=63)$, BBC Bitesize $(13.12 \%, n=50)$, Google $(12.34 \%, n=12.34 \%)$ and MS Teams $(11.55 \%, n=44)$. Applications that promoted interaction were considered particularly engaging, as children have "valued being able to discuss things with their peers and being able to see them" (Participant 529, Parent children in Year 3, Year 9 and Year 11), with videos made by teachers allowing children "to stay connected to the teachers every day" (Participant 524, Parents to children in Year 4, Year 7 and Year 11). Respondents were also asked to rate a series of statements about their own and their children's engagement (see Table 3). Overall, parents felt that learning using digital technology during lockdown 
did not help their children feel more engaged or learn better, with some expressing frustration and concern that they "[had] no guidance how to 'teach', no tasks set to send to the teachers... [and they felt] very lost and upset [their children] will be behind" (Participant 492, Parent of a child in Reception). Parents also reported that recorded lectures were helpful for their children's understanding (slightly higher for secondary school only families). Secondary only families also considered that their children's sense of responsibility for learning might have increased somewhat. Parents reported that they were more aware of the schoolwork that their children were doing during the lockdown, with increased visibility of learning, especially for the families of primary school only children, although this was possibly due to the greater need of younger children for direct assistance, as well as lacking IT skills ([6]). However, this increased awareness of learning did not extend to these parents having more discussions with their children's teachers, nor feeling more connected to the school community.

\section{CONCLUSIONS}

The results reveal that the COVID-19 pandemic has changed digital technology use and perceived usefulness. Unsurprisingly, digital technologies for uses in physical classrooms were reported to decrease during the pandemic. Recorded lectures, videos, learning platforms (i.e., Google Classroom) and conference tools for synchronous interaction were reported being used to support learning and replaced previously used tools (i.e., blogs, wikis) which support more asynchronous collaboration. However, parents also reported reduced contact with schools during lockdown via email, which may have resulted in a greater disconnect between teachers and parents. Although internet connection was reported to be broadly satisfactory, many families still reported sharing digital devices, impacting accessibility. Nevertheless, the digital disruption has brought about changes to social practices and ways for parents to engage with their children and become more involved in their school work, with a slight majority of parents reporting daily involvement in their child(ren)'s learning activities during COVID-19.

\section{REFERENCES}

[1] M. Castro, E. Expósito-Casas, E. López-Martín, L. Lizasoain, E. Navarro-Asencio, and J. L. Gaviria, "Parental involvement on student academic achievement: A meta-analysis," Educational Research Review, vol. 14, pp. 33-46, 2015, doi: 10.1016/j.edurev.2015.01.002.

[2] G. L. Doctoroff and D. H. Arnold, "Doing homework together: The relation between parenting strategies, child engagement, and achievement," Journal of Applied Developmental Psychology, vol. 48, pp. 103-113, 2017, doi: 10.1016/j.appdev.2017.01.001.

[3] M. C. Heatly and E. Votruba-Drzal, "Developmental precursors of engagement and motivation in fifth grade: Linkages with parent- and teacher-child relationships," Journal of Applied Developmental Psychology, 2018, doi: 10.1016/j.appdev.2018.09.003.

[4] J. Povey et al., "Engaging parents in schools and building parent-school partnerships: The role of school and parent organisation leadership," International Journal of Educational Research, vol. 79, pp. 128-141, 2016, doi: 10.1016/j.jijer.2016.07.005.

[5] C. Schneider and M. Arnot, "Transactional school-home-school communication: Addressing the mismatches between migrant parents' and teachers' views of parental knowledge, engagement and the barriers to engagement," Teaching and Teacher Education, vol. 75, pp. 10-20, 2018, doi: 10.1016/j.tate.2018.05.005.

[6] M. Bond, "Schools and emergency remote education during the COVID-19 pandemic: A living rapid systematic review," Asian Journal of Distance Education, vol. 15, no. 2, pp. 191-247, 2020. Retrieved from http://www.asianjde.com/ojs/index.php/AsianJDE/article/view/517.

[7] M. Bond, "Facilitating student engagement through the flipped learning approach in K-12: A systematic review," Computers \& Education, no. 151, pp. 1-36, 2020, doi: 10.1016/j.compedu.2020.103819.

[8] M. Bond, "Flipped learning and parent engagement in secondary schools: A South Australian case study," British Journal of Digital technology, vol. 50, no. 3, pp. 1294-1319, 2019, doi: 10.1111/bjet.12765.

[9] E. Gough, D. DeJong, T. Grundmayer, and M. Baron, "K-12 teacher perceptions regarding the Flipped Classroom Model for teaching and learning," Journal of Digital technology Systems, vol. 45, no. 3, pp. 390-423, 2017, doi: 10.1177/0047239516658444. 
[10] Education Endowment Foundation, "Working with parents to support children's learning," 2018. https://educationendowmentfoundation.org.uk/tools/guidance-reports/working-with-parents-tosupport-childrens-learning

[11] J. Goodall, "Technology and school-home communication," International Journal of Pedagogies \& Learning, vol. 11, no. 2, pp. 118-131, 2016, doi: 10.1080/22040552.2016.1227252.

[12] N. Bergdahl, "Emerging practices and persisting challenges - a year into distance education in upper secondary school," Published in the Proceedings of the Designs for Learning Conference, May 2425, Stockholm, Sweden, 2021.

[13] C. Giovannella, M. Passarelli, and D. Persico, "The Effects of the Covid-19 Pandemic on Italian Learning Ecosystems: the School Teachers' Perspective at the steady state," Interaction Design and Architecture(s) Journal, vol. 45, pp. 264-286, 2020.

http://www.mifav.uniroma2.it/inevent/events/idea2010/index.php?s=102\&link=ToC_45_P\&link=45 _12_abstract.

[14] N. livari, S. Sharma, and L. Ventä-Olkkonen, "Digital transformation of everyday life - How COVID19 pandemic transformed the basic education of the young generation and why information management research should care?," International Journal of Information Management, p. 102183, 2020, doi: 10.1016/j.ijinfomgt.2020.102183.

[15] Jæger M M and Blaabæk E H, "Inequality in learning opportunities during Covid-19: Evidence from library takeout," Research in Social Stratification \& Mobility, vol. 68, p. 100524, 2020, doi: 10.1016/j.rssm.2020.100524.

[16] U. Kaden, "COVID-19 School Closure-Related Changes to the Professional Life of a K-12 Teacher," Education Sciences, vol. 10, no. 6, 2020, doi: 10.3390/educsci10060165.

[17] G. Mascheroni et al., "Learning at a Distance: Children's remote learning experiences in Italy during the COVID-19 pandemic," UNICEF Office of Research - Innocenti, 2021. https://www.unicefirc.org/publications/1182-learning-at-a-distance-childrens-remote-learning-experiences-in-italyduring-the-covid-19-pandemic.html.

[18] B. Öckert, "Barn och unga under coronapandemin," 2021. https://www.ifau.se/globalassets/pdf/se/2021/r-2021-02-barn-och-unga-undercoronapandemin.pdf.

[19] OECD, PISA 2018 Results (Volume V): Effective Policies, Successful Schools: OECD, 2020, doi: 10.1787/ca768d40-en.

[20] L. Wößmann, V. Freundl, E. Grewenig, P. Lergetporer, K. Werner, and L. Zierow, "Bildung in der Coronakrise: Wie haben die Schulkinder die Zeit der Schulschließungen verbracht, und welche Bildungsmaßnahmen befürworten die Deutschen?," ifo Institut, München 9, 2020. https://www.ifo.de/publikationen/2020/aufsatz-zeitschrift/bildung-der-coronakrise-wie-haben-dieschulkinder-die-zeit.

[21] M. Bond and F. Bolan, What have we learned about online learning? UK and global evidence on the emergency remote education of schoolchildren during COVID-19. https://covidandsociety.com/ what-have-we-learned-about-online-learning-summary-evidence-emergency-remote-educationschoolchildren-during-covid-19/.

[22] Department for Education, Children of critical workers and vulnerable children who can access schools or educational settings. https://www.gov.uk/government/publications/coronavirus-covid-19maintaining-educational-provision/guidance-for-schools-colleges-and-local-authorities-onmaintaining-educational-provision.

[23] A. Andrew et al., "Inequalities in Children's Experiences of Home Learning during the COVID-19 Lockdown in England*," Fiscal Studies, vol. 41, no. 3, pp. 653-683, 2020, doi: 10.1111/14755890.12240.

[24] UNESCO Centre, School of Education, Ulster University, "Ulster University Northern Ireland Parent Surveys: Experiences of Supporting Children's Home Learning during COVID-19," 2020. https://www.ulster.ac.uk/_data/assets/pdf_file/0009/597969/UU-School-survey-Report-web.pdf.

[25] Education Scotland, "National overview of practice in remote learning: Parents, carers and learners," Livingston 3, 2021. https://education.gov.scot/media/mclbckrn/national-overview-ofpractice-in-remote-learning-3-parents-carers-and-learners.pdf. 
[26] K. Asbury, L. Fox, E. Deniz, A. Code, and U. Toseeb, "How is COVID-19 Affecting the Mental Health of Children with Special Educational Needs and Disabilities and Their Families?," Journal of autism and developmental disorders, 2020, doi: 10.1007/s10803-020-04577-2.

[27] A. Andrew et al., "Learning during the lockdown: Real-time data on children's experiences during home learning," IFS Briefing Note BN288, The Institute for Fiscal Studies, 2020.

https://www.ifs.org.uk/uploads/Edited_Final-BN288\%20Learning\%20during\%20the\%20 lockdown.pdf.

[28] E. Eivers, J. Worth, and A. Ghosh, "Home learning during Covid-19: Findings from the Understanding Society Longitudinal Study," National Foundation for Educational Research, Slough, 2020. https://www.nfer.ac.uk/media/4101/home_learning_during_covid_19_findings_from_the_ understanding_society_longitudinal_study.pdf.

[29] U. Toseeb, K. Asbury, A. Code, L. Fox, and E. Deniz, "Supporting Families with Children with Special Educational Needs and Disabilities During COVID-19," Pre-Print, 2020, doi: 10.31234/osf.io/tm69k.

[30] R. Yin, Case Study Research: Design and Methods, 5th ed. Thousand Oaks, CA: SAGE Publications, 2014.

[31] F. Baltar and I. Brunet, "Social research 2.0: virtual snowball sampling method using Facebook," Internet Research, vol. 22, no. 1, pp. 57-74, 2012, doi: 10.1108/10662241211199960.

[32] K. Browne, "Snowball sampling: using social networks to research non-heterosexual women," International Journal of Social Research Methodology, vol. 8, no. 1, pp. 47-60, 2005, doi: $10.1080 / 1364557032000081663$.

[33] S. Gehlert and J. Mozersky, "Seeing Beyond the Margins: Challenges to Informed Inclusion of Vulnerable Populations in Research," The Journal of Law, Medicine \& Ethics, vol. 46, no. 1, pp. 3043, 2018, doi: 10.1177/1073110518766006.

[34] L. Dempsey, M. Dowling, P. Larkin, and K. Murphy, "Sensitive Interviewing in Qualitative Research," Research in Nursing \& Health, vol. 39, no. 6, pp. 480-490, 2016, doi: 10.1002/nur.21743.

[35] J. Lee and R. Spratling, "Recruiting Mothers of Children With Developmental Disabilities: Adaptations of the Snowball Sampling Technique Using Social Media," Journal of Pediatric Health Care, vol. 33, no. 1, pp. 107-110, 2019, doi: 10.1016/j.pedhc.2018.09.011.

[36] M. Bond and N. Bergdahl, Digital technology and parent engagement in the UK during the COVID19 pandemic, 2021. https://www.researchgate.net/project/Educational-technology-and-parentengagement-in-the-UK-during-the-COVID-19-pandemic.

[37] O. Zawacki-Richter, C. Kramer, and W. Müskens, "Studiumsbezogene Mediennutzung im Wandel. Querschnittdaten 2012 und 2015 im Vergleich," Schriftenreihe zum Bildungs- und Wissenschaftsmanagement, no. 1, pp. 1-42, 2016. http://openjournal.unioldenburg.de/index.php/bildungsmanagement/article/view/101.

[38] Y.-N. Huang and Z.-R. Hong, "The effects of a flipped English classroom intervention on students' information and communication technology and English reading comprehension," Digital technology Research and Development, vol. 64, no. 2, pp. 175-193, 2016, doi: 10.1007/s11423-015-9412-7.

[39] S. C. Kong, "Parents' perceptions of e-learning in school education: implications for the partnership between schools and parents," Technology, Pedagogy and Education, vol. 27, no. 1, pp. 15-31, 2018, doi: 10.1080/1475939X.2017.1317659.

[40] L. Cohen, L. Manion, and K. Morrison, Research Methods in Education, 7th ed. Abingdon: Routledge, 2011. 